\title{
Enhanced mechanical, thermal and barrier properties of clay-based polymer nanocomposite systems
}

David P. PENALOZA Jr. S an associate professor in the Chemistry Department, College of Science, De La Salle University. His research interests focus on self-assembled systems and nanostructured materials.

David P. PENALOZA JR. " Chemistry Department, College of Science, De La Salle University, Manila, Philippines - david.penaloza.jr@dlsu.edu.ph

Érkezett: 2019. 01. 09. - Received: 09. 01. 2019. " https://doi.org/10.14382/epitoanyag-jsbcm.2019.13

\begin{abstract}
Silicate clay-based polymer nanocomposites derived from the use of an organically modified clay montmorillonite (MMT) mineral and other related materials have attracted a great deal of technological and scientific interest owing to the promise of greatly improved properties over those of the unfilled polymer. In this review, enhancement in different properties - e.g. mechanical strength, thermal stability and flammability as well as barrier properties - of the resulting nanohybrid materials through the incorporation of a modified clay to a bulk polymer - is discussed.
\end{abstract}

Keywords: clay-polymer nanocomposites, property enhancement, modified clay

Kulcsszavak: agyag-polimer nanokompozitok, tulajdonságjavítás, módosított agyag

\section{Introduction}

Clay-polymer hybrid materials are a class of inorganic-organic hybrids having a polymeric material reinforced with a small loading $(<10 \%)$ of clay fillers [1-10]. The term nanocomposite refers to a combination of two or more materials where one of the phases has one, two or three dimensions within the nanometer $\left(10^{-9} \mathrm{~m}\right)$ range [11]. Due to the small size and the high surface-to-volume ratio of the inorganic filler at this length scale, the polymer nanocomposites have exhibited remarkable property enhancements and new properties compared to their unfilled polymer and conventional composites.

Two important research outputs have contributed immensely in the increased attention in the field of polymer nanocomposites. First is the pioneering work of Toyota in the late 1980s where silicate-based nanocomposite was prepared from a polyamide by scientists from the Toyota's Central Research and Development Laboratories (CRDL) [12-18]. The researchers were able to synthesize nylon-clay hybrids (NCHs) using in situ intercalative polymerization technique. The NCHs have exhibited substantial increases in the tensile strength, Young's modulus and heat distortion temperature. These remarkable property enhancements led to the first commercial application of clay-filled polymer in the manufacture of timing belt cover on Toyota cars. Then in 1993, the research team of Vaia et al. [19] showed that it is possible to prepare a clay-based polymer nanocomposite by melt mixing polymers with clays previously modified with cationic organic surfactants. This process eliminates the use of organic solvents. This is very appealing from the point of view of the industries as claybased polymer-nanocomposites can be prepared using existing industrial setups. These two key studies have opened the doors for vigorous research works aimed at enhancing properties of various types of polymers in recent years [20].

\section{Mechanical performance}

In order to improve mechanical properties of polymers, fillers in the form of fibers, particles or platelets are incorporated in the polymer matrix to form a composite. Enhancement in properties of the resulting hybrids is exhibited even at relatively low filler content using nano-sized inorganic inclusions, such in the case of silicate platelets in clay-based polymer nanocomposites. Unlike traditional composites where as high as $50 \%$ by weight filler is needed to effect a substantial change in the mechanical properties, the incorporation of nanosized particles, like silicate platelets, can lead to a comparable property effect even at a very low clay loading ( $<10 \%$ weight).

The researchers from the Toyota's Central Research and Development Laboratories were the first to demonstrate in the 1980s that a substantial increase in the mechanical properties of a polyamide resin can be realized through reinforcing the nylon matrix with a silicate clay. They successfully prepared a nylon-clay hybrid $(\mathrm{NCH})$ that possessed improved mechanical and thermal properties - a higher modulus, an enhanced strength and a better heat distortion temperature - over the unfilled nylon. These property enhancements resulted in NCHs being applied to automotive timing belt covers as an engine part [14-18, 21-25].

Cho and Paul (2000) [26] compared the properties of a modified MMT filled-polyamide nanocomposite with a glass fiber-reinforced composite in studying the effect of using two different inorganic fillers in reinforcing the same polyamide matrix that the Toyota scientists used. About 38\% increase in the tensile modulus was observed when the nylon 6 matrix was filled with $5 \%$ wt organoclay (3.66 GPa) compared to the unfilled nylon $6(2.66 \mathrm{GPa})$. The same amount of glass fiber reinforcement (5\% wt) gives a lower tensile modulus (3.26 MPa, $23 \%$ improvement relative to the bulk nylon). However, when $5 \% \mathrm{wt}$ of the glass fiber was added to the $5 \%$ wt organoclayfilled nylon nanocomposite, the modulus is $81 \%$ higher $(4.82$ $\mathrm{GPa})$ than the neat polyamide. This significant increase only 
shows that a synergistic effect on the modulus was achieved when the clay-filled polyamide nanocomposite was used as the matrix to prepare a glass fiber-reinforced composite as measured value is far greater than the additive sum of the modulus of the individual nanofiller-reinforced nylons. The nanocomposites were prepared via direct melt compounding using a conventional twin screw extruder.

Various researchers have carried out research on the effect of clay additions on the structure and property of epoxies. Epoxies are important thermosetting polymers that are widely used as matrices of polymer composites, adhesives for aerospace applications and coatings for metals. For instance, Wang and Pinnavaia (1994) [27] reported enhanced mechanical properties of an epoxy system that is filled with delaminated MMT clay. The epoxide resin used is the diglycidyl ether of bisphenol A while the organoclay is an MMT clay previously modified with various ammonium alkyl halides. The epoxy resin is heated with the onium ion exchanged form of the MMT in the presence of diamine curing agent. The long-chain alkyl surfactants facilitate the insertion of the epoxy monomer in the clay galleries promoting the epoxide polymerization between platelets. They found that the length of the intercalating agent affects the final morphology of the clay filler. For instance, the nanocomposites formed from the incorporation of a MMT clay modified with $\mathrm{CH}_{3}\left(\mathrm{CH}_{2}\right)_{7} \mathrm{NH}_{3}^{+}, \mathrm{CH}_{3}\left(\mathrm{CH}_{2}\right)_{11} \mathrm{NH}_{3}^{+}$and $\mathrm{CH}_{3}\left(\mathrm{CH}_{2}\right)_{15} \mathrm{NH}_{3}^{+}$yield exfoliated nanocomposite as shown by the absence of the $d_{001}$ spacing in their XRD plots. The use of shorter alkyl ammonium cations produced intercalated structure.

The mechanical properties of this hybrid have remarkably improved compared to the neat epoxy. For example, the tensile strength and modulus of the epoxy system filled with $\mathrm{CH}_{3}\left(\mathrm{CH}_{2}\right)_{17}-\mathrm{NH}_{3}{ }^{+}$-MMT increases with an increasing clay reinforcement. At the addition of only $15 \mathrm{wt} \%$ of the exfoliated organoclay, more than a ten-fold increase in the strength and modulus compared to the unfilled epoxy. Also, the strain at break for the prepared epoxy-clay composites remains the same as the pristine matrix suggesting that the clay filler nanoparticles do not disrupt continuity of the epoxy matrix.

The organoclay incorporation is also found effective in reinforcing polyurethanes [28-31]. Wang and Pinnavaia (1998) [32] reported an increase in the strength and toughness of a polyurethane nanocomposite enhanced with an MMT organoclay. A polyurethane matrix was filled with a modified MMT clay. Initially, the MMT was derivatized by replacing the exchangeable cations of the native mineral with the more organophillic alkyl ammonium ions, $\mathrm{C}_{18} \mathrm{H}_{37} \mathrm{NH}_{3}{ }^{+}$. At a loading of only $10 \mathrm{wt} \%$ of the organoclay, the strength and modulus of the nanocomposites are more than doubled while also increasing the strain-at-break. Another group, Wei et al. (2000) [33] also reported improved mechanical properties for the PUMMT nanocomposites prepared via in situ polymerization. The addition of only 1 wt\% of MMT clay modified with tris(hydroxymethyl)aminomethane to a PU matrix results in a $34 \%$ increase in Young's modulus, a 1.7-times increase in tensile strength and a 1.3-fold increase in the elongation at break of the PU-MMT nanocomposite. Song et al. (2003) [34] noted enhanced tensile strength (120\% increase) and doubled elongation at break when MMT clay was added to a PU matrix.

These property enhancements were found to be dependent on the silicate content of the nanocomposite. The common observation in the mechanical property measurements of the polymer nanocomposites enhanced with clay fillers is that it is very unusual to improve modulus and strength while at the same time significantly improving toughness of the bulk material [35]. The enhancement in strength and modulus is directly attributable to the reinforcement provided by the dispersed silicate nanolayers. The authors suggested that the improved elasticity that they observed for their nanocomposite may be attributed in part to the plasticizing effect of the gallery onium ions that are used to previously modify the silicate fillers prior to their incorporation in the polymer matrix.

The remarkable mechanical property improvements of the nanocomposites like significantly enhanced stiffness and tensile strength observed through the clay incorporation in engineering plastics have attracted interest in the use of silicate clays to improve some physical attributes of thermoplastic olefins [36-37]. To improve their properties, the nanocomposites derived from the incorporation of silicate clays onto these poly(olefins) have been studied [38-41]. Two examples of widely used commodity thermoplastic olefins are poly(propylene) and poly(ethylene)

Hasegawa and co-workers (1998) [37] prepared clay-based polypopylene nanocomposites using a maleic anhydridemodified PP oligomer(PP-MA) as a compatibilizer. The polymer matrix was melt-blended with a silicate clay that was previously treated with the compatibilizer. Remarkable mechanical property enhancements were noted in the nanocomposites. The dynamic storage moduli of the nanocomposites were higher than that of the unmodified poly(propylene) up to 130 ${ }^{\circ} \mathrm{C}$. The modulus of the nanocomposite containing $5 \mathrm{wt} \%$ clay and $22 \mathrm{wt} \%$ PP-MA nearly doubled compared to that of plain poly(propylene) at $80^{\circ} \mathrm{C}$. As the dispersibility of the clays was improved, the reinforcement effect of the clays was also increased. The authors noted that the clay particles became smaller and were dispersed more uniformly, as the ratio of compatibilizer to the clay was increased.

Parent and co-researchers (2002) [42] observed significant property enhancement in the Young's modulus of exfoliated clay-based poly(ethylene) nanocomposites compared to the unfilled poly(ethylene). The nanocomposites containing $5 \mathrm{wt} \%$ and $10 \%$ Nanomer I.44PA led to an increase of $30 \%$ $(220 \mathrm{MPa})$ and $53 \%(258 \mathrm{MPa})$, respectively compared to the neat poly(ethylene) (183 MPa). The anhydride-modified poly(ethylene) (PE-g-MAn) has a Young's modulus of $169 \mathrm{MPa}$. The nanocomposites were prepared by melt compounding a commercial organoclay Nanomer 1.44PA (Nanocor Inc.) that is ion-exchanged with a dimethyldialkylammonium halide $\left(70 \% \mathrm{C}_{18}, 26 \% \mathrm{C}_{16}\right.$ and $4 \% \mathrm{C}_{14}$ ) in a matrix of graft-modified poly(ethylene) (PE-g-MAn, Fusabond ${ }^{\circledR}$ M611-25, DuPont Canada, MFI=9.6). PE-g-MAn contains approximately $1 \% \mathrm{wt}$ of maleic anhydride as modifier.

Based on their studies of melt compounding various pre-treated organoclay into a matrix of linear low density poly(ethylene) to prepare clay-based polymer nanocomposites, Hotta and Paul (2004) [43] observed that in some cases, a small 
clay loading (about 5\%) resulted to doubling of the modulus. The morphological studies of these nanocomposites using WAXD and TEM revealed the clay was largely exfoliated.

The above mentioned improvements in the mechanical properties of nanocomposites have attracted attention for the use of these materials in various automotive and industrial applications. These include their use in the car industry as mirror housings, engine and timing belt covers, door handles and intake manifold. They are also being currently considered in the manufacture of parts for general use equipment as housings for power tools, impellers and blades for vacuum cleaners and covers for portable electronic equipment.

\section{Thermal stability and flammability}

It has been reported that the MMT clay when used as fillers can be used to enhance thermal stability and reduce flammability of some polymers.

Burnside and Giannelis (1995)[44] reported a clay-based poly(dimethylsiloxane) (PDMS) nanocomposite that is significantly more thermally stable compared to a neat PDMS polymer. The nanocomposite was prepared by sonicating a silanol-terminated PDMS (18,000 g/mole) with MMT, that is ion exchanged with a dimethyl ditallow ammonium salt. A tallow is a naturally-occurring hydrocarbon that contains a mixture of various lengths of alkyl chains $\left(\mathrm{C}_{18}-65 \mathrm{wt} \%, \mathrm{C}_{16}-30\right.$ $w t \%$ and $\left.\mathrm{C}_{14}-5 \mathrm{wt} \%\right)$. The nanocomposite contains only $10 \%$ mass fraction of the modified clay. At $50 \%$ weight loss (Fig. 1), the nanocomposite has displayed more than $140{ }^{\circ} \mathrm{C}$ increase in its degradation temperature than the unfilled PDMS. The increased thermal stability was attributed by the authors to the hindered diffusion of volatile decomposition products from the nanocomposite. X-ray diffraction showed that the clay filler was exfoliated as the nanocomposite had a featureless X-ray pattern indicating a disordered-delaminated nanostructure.

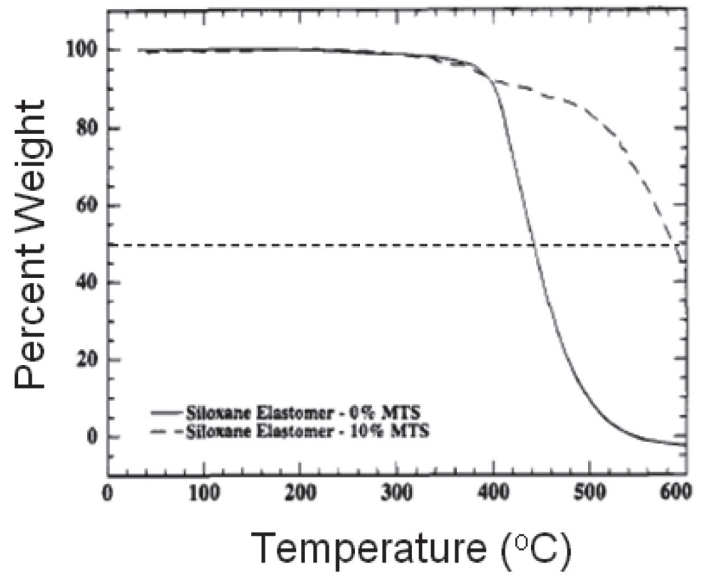

Fig. 1. A nanocomposite prepared by incorporating well dispersed MMT clay platelets in a poly(dimethysiloxane) (PDMS) matrix exhibited a substantial increase in its degradation temperature by as much as $140^{\circ} \mathrm{C}$ at $50 \%$ weight loss compared to an unfilled PDMS polymer as shown in this TGA thermogram [44]

1. ábra A diszpergált MMT-agyaglemezek poli(dimetil-sziloxán) (PDMS) mátrixba való beépitésével elóálított nanokompozit jelentősen megnövelte a lebomlási hömérsékletet (akár $140^{\circ} \mathrm{C}$-kal, 50\% -os tömegveszteségnél), normál PDMS polimerhez képest, amint azt a TGA ábra mutatja [44]

Using melt intercalation, a poly(ester) nanocomposite was prepared by incorporating an MMT clay that is previously ion exchanged with an ammonium tallow. The nanocomposite obtained using poly(butylene terephthalate) (PBT) containing $3 \%$ telechelic ionic groups dispersed with $5 \%$ of the organoclay exhibited improved thermal characteristics. It has a heat distortion temperature (HDT) that is $48{ }^{\circ} \mathrm{C}$ higher compared to that of the unfilled PBT. Also, the thermogravimetric analysis revealed higher heat decomposition temperature of the nanocomposite compared to the neat poly(ester) [45].

Clay-based polymer nanocomposites were also found to exhibit a substantial increase in the flame retardancy relative to the bare polymer. The flame retardancy effect appears to originate from the ability of the clay to promote char formation. The char layer acts as a barrier that slows down the heat transfer and retards the movement of gases to feed the flame [46].

The presence of nanosized silicate clays was found to promote char formation as confirmed by several studies. Vaia et al. (1999) [47] on poly(amide)-silicate nanocomposites showed increased yield in the amount of carbonaceous char when silicate clays are added. This observation of the ability of clay to promote char formation has been verified by several authors even for polymeric systems that do not normally show tendency to form char. This was reported by Wilkie et. al (2004) [48] in the preparation of a clay-based poly(styrene) nanocomposite. The clay-poly(styrene) nanocomposite was prepared via bulk polymerization using organomodified MMT clay. Prior to the polymerization of the styrene, the clay was ion exchanged with an alkyl ammonium salt containing a $\mathrm{C}_{16}$ chain, N,N-dimethyl-n-hexadecyl-(4-vinylbenzyl) ammonium chloride. The nanocomposite and unfilled PBT samples were subjected to a thermogravimetric analysis to study their thermal behavior. Under thermo-oxidative conditions, while the onset degradation temperature is not significantly increased, the char content of the poly(styrene) reinforced with the modified MMT is remarkably increased from 6 to $15 \% \mathrm{wt}$ at $400{ }^{\circ} \mathrm{C}$. The presence of clay promotes char formation during the thermo-oxidative degradation of the polymer. The char provides a transient protective barrier to the nanocomposite in combination with the silicate clay platelets acting as barrier.

Other research works also showed similar observation: like in the case of poly(ethylene) [49] poly(propylene) [50], poly(styrene) [48], acrylonitrile-butadiene-styrene copolymer (ABS) [51] and ethylene-vinyl-acetate (EVA) copolymer [52].

The char formation is complex and involves several processes [53]. A two-step mechanism was proposed by Benson and Nogia (1979) [54] to explain the oxidation chain reactions of organic molecules during thermal degradation. The first step involves chain scission of the polymer subsequently followed by volatilization. This happens at a low temperature. At a higher temperature, oxidative dehydrogenation becomes more probable producing thermally stable aromatic charred structures due to the formation of conjugate double bond sequences. In the presence of a silicate clay as a filler in the nanocomposite, the oxidative dehydrogenation dominates as evidenced by the enhanced aromatization and reduced rate of oxidation [52, 55]. Hence, the clay induces transient char formation which only started to degrade at high temperatures.

The cone calorimeter measurement is one of the most useful bench-scale methods to characterize the flammability 
properties of various clay-based polymer nanocomposites. In a cone calorimeter experiment, flammability properties like heat release rate (HRR), peak heat release rate (PHRR), time to ignition (TTI), total heat released (THR) and mass loss rate (MLR) can be determined. HRR and PHRR are two important parameters to evaluate fire safety [56]. HRR is thought of as the driving force of fire while PHRR represents the point in a fire where heat is apt to propagate further or ignite adjacent objects [56]. In studying the thermal properties of clay-polymer nanocomposites using cone calorimeter experiments, other remarkable characteristics were also noted. PHRR and HRR are reduced upon incorporation of nanosized clay [46]. The time to ignition is also slightly lowered.

\section{Barrier applications}

Clay-based polymer nanocomposites have also shown better barrier properties in the nanocomposites compared to their unfilled polymer counterparts due to the reduced permeability against gas and solvent permeating molecules. Well-dispersed, randomly oriented single sheets of clay in the polymer matrix hinder the permeating molecules as these individual clay sheets serve as impermeable barriers in the path of the diffusion process (Fig. 2). When the layers are delaminated, the effective path length for molecular diffusion is increased. The dispersed platelets of the silicate clays make the permeating gas and liquid molecules undergo a tortuous path. This "maze" of clay platelets retards the progress of the gas and liquid molecules through the polymer matrix, hence the observed reduction in permeability. The reduced gas and liquid permeability of the nanocomposites make them attractive for barrier applications e.g. membrane separation and packaging applications.

An onium-alkyl modified MMT was melt-mixed with a polyolefin. The nanocomposite was produced by a gradual dilution of the intercalated MMT edge-modified with 1-hydroxydodecane-1,1-diphosphonic acid in the melt high density poly(ethylene) until a final clay concentration of 0.3 wt $\%$ was reached. Compared to the unmodified HDPE, oxygen and water vapor permeabilities were reduced by approximately 55 and $70 \%$, respectively [57].

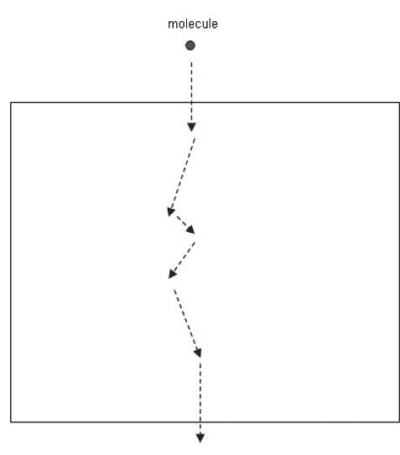

Pure polymer

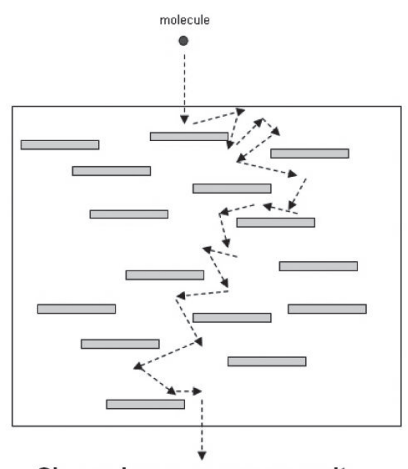

Clay-polymer nanocomposite
Fig. 2. Randomly well-dispersed clay platelets serve as barriers making gas molecules pass through a 'torturous path' compared to unhindered path in pure polymer matrix

2. ábra A véletlenszerüen elhelyezkedő agyaglemezek gátként viselkednek és jelentősen akadályozzák a gáz molekulák egyenletes átáramlását, ahogy az a tiszta polimer mátrixban megfigyelhetó
Messermith and Giannelis (1995) [58] showed that the permeability of a biodegradable aliphatic polyester to water can be remarkably reduced through the incorporation of welldispersed, delaminated silicate clay platelets. The permeability of the films of the polymer nanocomposites to water vapor is significantly decreased with increasing silicate content. At $4.8 \%$ volume silicate content, the permeability of the nanocomposite is reduced by an order of magnitude compared to the unfilled poly(e-caprolactone). The nanocomposite synthesis involves the use of a montmorillonite clay that is ion-exchanged with protonated amino acids. The acid groups initiated the ring opening polymerization (ROP) of the heterocyclic monomer to prepare the clay-poly(e-caprolactone) nanocomposites, resulting in polymer chains that are ionically anchored to the silicate layers. The gallery polymerization was believed to promote the delamination/dispersion of the host layers during the ring-opening polymerization of the e-caprolactone monomer. X-ray diffraction patterns for the derived nanocomposites exhibit no (001) reflections due to the clay fillers suggesting that individual silicate layers were dispersed in the polymer matrix.

Chang and co-workers (2003) [59] studied the effect of using different kinds of organomodified silicate clays on the oxygen gas permeability of poly(lactic acid) (PLA) nanocomposites. The increasing amount of modified clays in the PLA nanocomposites prepared by melt intercalation systematically decreased the oxygen gas permeability of the nanocomposite films. At $10 \mathrm{wt} \%$, the permeability value of the nanocomposites is reduced by half compared to the permeability of the unfilled PLA film regardless of the type of organically modified clay used as fillers. The authors attributed the decrease in the oxygen permeability of the nanocomposite films to the increase in the lengths of the tortuous paths posed by the individually dispersed clay nanoplatelets in the nanocomposites.

\section{Conclusions}

The enhancement in the physical properties, such as mechanical, thermal and barrier properties of the nanocomposites, is observed when the incorporation of an organoclay to a polymer matrix led to randomly dispersed, individually delaminated silicate platelets to prepare claybased polymer nanocomposites. To achieve this, issues on clay filler and polymer compatibility and uniform dispersion of the clay within the polymeric matrix should be addressed.

\section{Acknowledgment}

The author would like to thank Prof. Thomas AP Seery of the University of Connecticut for his insightful comments during the preparation of this article.

\section{References}

[1] Penaloza, D. P. (2016): Mechanical and thermal properties of claypoly(norbornene) nanocomposites from ruthenium alkylidenemediated surface-initiated polymerization. Kimika (The Journal of the Chemical Society of the Philippines), Vol. 27, No. 1: pp. 23-9. https://doi.org/10.26534/kimika.v27i1.22-28

[2] Cabedo, L. - Villanueva, M. P. - Lagarón, J. M. - Giménez, E. (2017): Development and characterization of unmodified kaolinite/EVOH 
nanocomposites by melt compounding. Applied Clay Science, Vol. 135, pp. 300-306. https://doi.org/10.1016/j.clay.2016.10.008

[3] Geyer, B. - Hundshammer, T. - Röhner, S. - Lorenz, G. - Kandelbauer, A. (2014): Predicting thermal and thermo-oxidative stability of silanemodified clay minerals using thermogravimetry and isoconversional kinetic analysis. Applied Clay Science, Vol. 101, pp. 253-259. https://doi.org/10.1016/j.clay.2014.08.011

[4] Natkański, P. - Kuśtrowski, P. - Białas, A. - Piwowarska, Z. - Michalik, M. (2013): Thermal stability of montmorillonite polyacrylamide and polyacrylate nanocomposites and adsorption of $\mathrm{Fe}(\mathrm{III})$ ions. Applied Clay Science, Vol. 75-76, pp. 153-157. https://doi.org/10.1016/j.clay.2013.02.002

[5] Penaloza, D. P. - Seery, T. A. P. (2018): Silylated functionalized montmorillonite clay for nanocomposite preparation. Journal of Silicate Based and Composite Materials. Vol. 70, No. 5, pp. 140-145. https://doi.org/10.14382/epitoanyag-jsbcm.2018.26

[6] Giannelis, E. P. (1996): Polymer layered silicate nanocomposites. Advanced Materials, Vol. 8, No. 1, pp. 29-35. https://doi.org/10.1002/adma.19960080104

[7] Ogasa, T. - Takahashi, J. - Kemmochi, K. (1995): Polymer-based composite materials in general industrial fields. Advanced Composite Materials: The Official Journal of the Japan Society of Composite Materials, Vol. 4, No. 3, pp. 221-235. https://doi.org/10.1163/156855195X00032

[8] Ogawa, M. - Kuroda, K. (1997): Preparation of inorganic-organic nanocomposites through intercalation of organoammonium ions into layered silicates. Bulletin of the Chemical Society of Japan, Vol. 70, No. 11, pp. 2593-2618. https://doi.org/10.1246/bcsj.70.2593

[9] Alexandre, M. - Beyer, G. - Henrist, C. - Cloots, R. - Rulmont, A. Jerome, R. - Dubois, P. (2001): One-pot preparation of polymer/clay Nanocomposites starting from $\mathrm{Na}^{+}$montmorillonite. 1. Melt intercalation of ethylene/vinyl acetate copolymer. Chemistry of Materials.Vol. 13, No. 11, pp. 3830-3832. https://doi.org/10.1021/cm011095m

[10] Fu, X. - Qutubuddin, S. (2001): Polymer-clay nanocomposites: exfoliation of organophilic montmorillonite nanolayers in polystyrene. Polymer, Vol. 42, No. 2, pp. 807-13. https://doi.org/10.1016/S0032-3861(00)00385-2

[11] Goldstein, A.N. (Ed.). (1997): Handbook of nanophase materials. CRC Press

[12] Hasegawa, N. - Okamoto, H. - Kawasumi, M. - Kato, M. - Tsukigase, A. - Usuki, A. (2000): Polyolefin-clay hybrids based on modified polyolefins and organophilic clay. Macromolecular Materials and Engineering. Vol. 280-281, No. 1, pp. 76-79.

https://doi.org/10.1002/1439-2054(20000801)280:1<76::AID-MAME76>3.0.CO;2-\%23

[13] Kawasumi, M. (2004): The discovery of polymer-clay hybrids. Journal of Polymer Science Part A: Polymer Chemistry. Vol. 42, No. 4, pp. 819-824. https://doi.org/10.1002/pola.10961

[14] Kojima, Y. - Usuki, A. - Kawasumi, M. - Okada, A. - Kurauchi, T. Kamigaito, O. - Kaji, K. (1994): Fine structure of nylon-6-clay hybrid. Journal of Polymer Science Part B-Polymer Physics, Vol. 32, No. 4, pp. 62530. https://doi.org/10.1002/polb.1994.090320404

[15] Usuki, A. - Kawasumi, M. - Kojima, Y. - Okada, A. - Kurauchi, T. (1995): Synthesis and Properties of Diamine-Modified Nylon 6-Clay Hybrid. Kobunshi Ronbunshu, Vol. 52, No. 7, pp. 440-444. https://doi.org/10.1295/koron.52.440

[16] Usuki, A. - Koiwai, A. - Kojima, Y. - Kawasumi, M. - Okada, A. Kurauchi, T. Kamigaito, O. (1995): Interaction of nylon 6-clay surface and mechanical properties of nylon 6-clay hybrid. Journal of Applied Polymer Science, Vol. 55, No. 1, pp. 119-123. https://doi.org/10.1002/app.1995.070550113

[17] Yano, K. - Usuki, A. - Okada, A. (1997): Synthesis and properties of polyimide-clay hybrid films. Journal of Polymer Science Part A: Polymer Chemistry, Vol. 35, No. 11, pp. 2289-2894. https://doi.org/10.1002/(SICI)1099-0518(199708)35:11<2289::AID-POLA20>3.0.CO;2-9

[18] Yano, K. - Usuki, A. - Okada, A. - Kurauchi, T. - Kamigaito, O. (1993): Synthesis and properties of polyimide-clay hybrid. Journal of Polymer Science Part A: Polymer Chemistry, Vol. 31, No. 10, pp. 2493-2498. https://doi.org/10.1002/pola.1993.080311009

[19] Vaia, R.A. - Ishii, H. - Giannelis, E.P. (1993): Synthesis and properties of two-dimensional nanostructures by direct intercalation of polymer melts in layered silicates. Chemistry of Materials, Vol. 5, No. 12, pp. 1694-1696. . https://doi.org/10.1021/cm00036a004
[20] Penaloza DP. (2017): Review on the preparation, structure and property relation of clay-based polymer nanocomposites. Kimika (The Journal of the Chemical Society of the Philippines), Vol. 28, No. 1, pp. 44-56. https://doi.org/10.26534/kimika.v28i1.44-56

[21] Chen, J. - Beake, B.D. - Bell, G.A. - Tait, Y. Gao, F. (2016): Investigation of the nanomechanical properties of nylon 6 and nylon 6/clay nanocomposites at sub-ambient temperatures. Journal of Experimental Nanoscience, Vol.11, No. 9, pp. 695-706. https://doi.org/10.1080/17458080.2015.1136847

[22] Haider, S. - Kausar, A. - Muhammad, B. (2016): Research advancement in high-performance polyamides and polyamide blends loaded with layered silicate. Polymer - Plastics Technology and Engineering, Vol. 55, No. 14, pp. 1536-1556. https://doi.org/10.1080/03602559.2016.1163602

[23] Khalid Saeed I. (2017): Morphological, thermal, mechanical and solvent uptake of clay/nylon 6,6 composites. Journal of the Chilean Chemical Society, Vol. 62, No. 3, pp. 3562-3565. http://dx.doi.org/10.4067/s0717-97072017000303562

[24] Vyas, A. - Iroh, J.O. (2016): Clay induced thermoplastic crystals in thermoset matrix: thermal, dynamic mechanical, and morphological analysis of clay/nylon-6-epoxy nanocomposites. Polymer Composites, Vol. 37, No. 7, pp. 2206-2217. https://doi.org/10.1002/pc.23399

[25] Xu, W. - Wu, X. - Sun W. (2016): Molecular dynamics studies on the overall compressive modulus of nylon 6/montmorillonite nanocomposites. Advances in Mechanical Engineering. Vol. 8, No. 11, pp. 1-8. https://doi.org/10.1177/1687814016677659

[26] Cho, J.W. - Paul, D.R. (2001): Nylon 6 nanocomposites by melt compounding. Polymer, Vol. 42, No. 3, pp. 1083-10894. https://doi.org/10.1016/S0032-3861(00)00380-3

[27] Lan, T. - Pinnavaia, T.J. (1994): Clay-reinforced epoxy nanocomposites. Chemistry of Materials, Vol. 6, No. 12, pp. 2216-2219. https://pubs.acs.org/doi/10.1021/cm00048a006

[28] Adak, B. - Butola, B.S. - Joshi, M. (2018): Effect of organoclay-type and clay-polyurethane interaction chemistry for tuning the morphology, gas barrier and mechanical properties of clay/polyurethane nanocomposites. Applied Clay Science, Vol. 161, pp. 343-53. https://doi.org/10.1016/j.clay.2018.04.030

[29] Ashhari, S. - Sarabi, A.A. (2017): Effects of organically modified nanoclay particles on the mechanical properties of aliphatic polyurethane/clay nanocomposite coatings. Polymer Composites, Vol. 38, No. 6, pp. 11671174. https://doi.org/10.1002/pc. 23680

[30] Peng, S. - Iroh, J.O. (2016): Synthesis and characterization of crosslinked polyurethane/clay nanocomposites. Journal of Applied Polymer Science, Vol. 133, Issue 17), 43346. https://doi.org/10.1002/app.43346

[31] Wang, X.C. - Geng, T. - Han, J. - Liu, C.T. - Shen, C.Y. - Turng, L.S. - Yang, H.E. (2017): Effects of nanoclays on the thermal stability and flame retardancy of microcellular thermoplastic polyurethane nanocomposites. Polymer Composites, Vol. 39, No. S3, E1429-E1440. https://doi.org/10.1002/pc.24340

[32] Wang, Z. - Pinnavaia, T.J. (1998): Nanolayer reinforcement of elastomeric polyurethane. Chemistry of Materials, Vol. 10, No. 12, pp. 3769-3771. https://doi.org/10.1021/cm980448n

[33] Chen, T.K. - Tien, Y.I. - Wei, K.H. (2000): Synthesis and characterization of novel segmented polyurethane/clay nanocomposites. Vol. 41, No. 4, pp. 1345-1353. https://doi.org/10.1016/S0032-3861(99)00280-3

[34] Song, M. - Hourston, D.J. - Yao, K.J. - Tay, J.K.H. - Ansarifar, M.A. (2003): High performance nanocomposites of polyurethane elastomer and organically modified layered silicate. Journal of Applied Polymer Science, Vol. 90, No. 12, pp. 3239-3243. https://doi.org/10.1002/app.12979

[35] Tjong, S.C. - Meng, Y.Z. (2003): Preparation and characterization of melt-compounded polyethylene/vermiculite nanocomposites. Journal of Polymer Science Part B: Polymer Physics, Vol. 41, No. 13, pp. 1476-1484. https://onlinelibrary.wiley.com/doi/10.1002/polb.10497

[36] Usuki, A. - Kato, M. - Okada, A. - Kurauchi, T. (1997): Synthesis of polypropylene-clay hybrid. Journal of Applied Polymer Science, Vol. 63, No. 1, pp. 137-138. https://doi.org/10.1002/(SICI)1097-4628(19970103)63:1<137::AID-APP15>3.0.CO;2-2

[37] Hasegawa, N. - Kawasumi, M. - Kato, M. - Usuki, A. - Okada, A. (1998): Preparation and mechanical properties of polypropylene-clay hybrids 
using a maleic anhydride-modified polypropylene oligomer. Journal of Applied Polymer Science, Vol. 67, No. 1, pp. 87-92.

https://doi.org/10.1002/(SICI)1097-4628(19980103)67:1<87::AID-APP10>3.0.CO;2-2

[38] Maiti, P. - Nam, P.H. - Okamoto, M. - Hasegawa, N. - Usuki A. (2002): Influence of crystallization on intercalation, morphology, and mechanical properties of polypropylene/clay nanocomposites. Macromolecules, Vol. 35, No. 6, pp. 2042-2049. https://doi.org/10.1021/ma010852z

[39] Chiu, F.C. - Lai, S.M. - Chen, J.W. - Chu, P.H. Combined effects of clay modifications and compatibilizers on the formation and physical properties of melt-mixed polypropylene/clay nanocomposites. Journal of Polymer Science Part B: Polymer Physics. Vol. 42, No. 22, pp. 4139-4150. https://doi.org/10.1002/polb.20271

[40] Morawiec, J. - Pawlak, A. - Slouf, M. - Galeski, A. - Piorkowska, E. Krasnikowa, N. (2005): Preparation and properties of compatibilized LDPE/organo-modified montmorillonite nanocomposites. European Polymer Journal, Vol. 41, No. 5, pp. 1115-1122. https://doi.org/10.1016/j.eurpolymj.2004.11.011

[41] Shah, R.K. - Paul, D.R. (2006): Organoclay degradation in melt processed polyethylene nanocomposites. Vol. 47, No. 11, pp. 4075-4084. https://doi.org/10.1016/j.polymer.2006.02.031

[42] Gopakumar, T.G. - Lee, J.A. - Kontopoulou, M. - Parent, J.S. (2002) Influence of clay exfoliation on the physical properties of montmorillonite/ polyethylene composites. Polymer, Vol. 43, No. 20, pp. 5483-5491. https://doi.org/10.1016/S0032-3861(02)00403-2

[43] Hotta, S. - Paul, D.R. (2004): Nanocomposites formed from linear low density polyethylene and organoclays. Polymer, Vol. 45, No. 22, pp. 76397654. https://doi.org/10.1016/j.polymer.2004.08.059

[44] Burnside, S.D. - Giannelis, E.P. (1995): Synthesis and properties of new poly(dimethylsiloxane) nanocomposites. Chemistry of Materials, Vol. 7, No. 9, pp. 1597-1600. https://doi.org/10.1016/10.1021/cm00057a001

[45] Colonna, M. - Berti, C. - Binassi, E. - Fiorini, M. - Karanam, S. - Brunelle, D.J. (2010) Nanocomposite of montmorillonite with telechelic sulfonated poly(butylene terephthalate): effect of ionic groups on clay dispersion, mechanical and thermal properties. European Polymer Journal, Vol. 46, No. 5, pp. 918-927. https://doi.org/10.1016/j.eurpolymj.2010.02.003

[46] Powell, C.E. - Beall, G.W. (2006): Physical properties of polymer/clay nanocomposites. Current Opinion in Solid State and Materials Science, Vol. 10, No. 2, pp. 73-80. https://doi.org/10.1016/10.1016/j.cossms.2006.09.001

[47] Vaia, R.A. - Price, G. - Ruth P.N. - Nguyen, H.T. - Lichtenhan, J. (1999): Polymer/layered silicate nanocomposites as high performance ablative materials. Applied Clay Science, Vol. 15, No. 1-2, pp. 67-92. https://doi.org/10.1016/S0169-1317(99)00013-7

[48] Bourbigot, S. - Gilman, J.W. - Wilkie, C.A. (2004): Kinetic analysis of the thermal degradation of polystyrene-montmorillonite nanocomposite. Polymer Degradation and Stability. 2004;84(3):483-92. https://doi.org/10.1016/j.polymdegradstab.2004.01.006
[49] Zanetti, M. - Bracco, P. - Costa, L. (2004): Thermal degradation behaviour of PE/clay nanocomposites. Polymer Degradation and Stability, Vol. 85, No. 1, pp. 657-665. https://doi.org/10.1016/j.polymdegradstab.2004.03.005

[50]Zanetti, M. - Camino, G. - Reichert, P. - Mülhaupt, R. (2001): Thermal behaviour of poly(propylene) layered silicate nanocomposites. Macromolecular Rapid Communications. Vol. 22, No. 3, pp. 176-180. https://doi.org/10.1002/1521-3927(200102)22:3<176::AID-MARC176>3.0.CO;2-C

[51] Wang, S. - Hu, Y. - Lin, Z. - Gui, Z. - Wang, Z. - Chen, Z. - Fan, W. (2003): Flammability and thermal stability studies of ABS/montmorillonite nanocomposite. Polymer International, Vol. 52, No. 6, pp. 1045-1049. https://doi.org/10.1002/pi.1200

[52] Zanetti, M. - Camino, G. - Thomann, R. - Mülhaupt, R. (2001): Synthesis and thermal behaviour of layered silicate-EVA nanocomposites. Polymer, Vol. 42, No. 10, pp. 4501-4517. https://doi.org/10.1016/S0032-3861(00)00775-8

[53] Levchik, S.W. - Wilkie, C.A. (Eds.). (2000): Fire retardancy of polymeric materials. CRC Press.

[54] Benson, S.W. - Nangia, P.S. (1979): Some unresolved problems in oxidation and combustion. Accounts of Chemical Research, Vol. 12, No. 7, pp. 223-228. https://doi.org/10.1021/ar50139a001

[55] Zanetti, M. - Camino, G. - Thomann, R. - Mülhaupt R. (2001): Synthesis and thermal behaviour of layered silicate-EVA nanocomposites. Polymer, Vol. 42, No. 10, pp. 4501-4507. https://doi.org/10.1016/S0032-3861(00)00775-8

[56] Kiliaris, P. - Papaspyrides, C.D. (2010): Polymer/layered silicate (clay) nanocomposites: An overview of flame retardancy. Progress in Polymer Science, Vol. 35, No. 7, pp. 902-958.

https://doi.org/10.1016/j.progpolymsci.2010.03.001

[57] Chaiko, D.J. (2006): Activation of organoclays and preparation of polyethylene nanocomposites. E-Polymers, Vol. 6, No. 1 . https://doi.org/10.1515/epoly.2006.6.1.242

[58] Messersmith, P.B. - Giannelis, E.P. (1995): Synthesis and barrier properties of poly(e-caprolactone)-layered silicate nanocomposites. Journal of Polymer Science Part A: Polymer Chemistry, Vol. 33, No. 7, pp. 1047-1057. https://doi.org/10.1002/pola.1995.080330707

[59] Chang, J.H. - An, Y.U. - Sur, G.S. (2003): Poly(lactic acid) nanocomposites with various organoclays. I. Thermomechanical properties, morphology, and gas permeability. Journal of Polymer Science Part B: Polymer Physics, Vol. 41, No. 1, pp. 94-103. https://doi.org/10.1002/polb.10349

$\underline{\text { Ref.: }}$

David P., Penaloza Jr.: Enhanced mechanical, thermal and barrier properties of clay-based polymer nanocomposite systems Építőanyag - Journal of Silicate Based and Composite Materials, Vol. 71, No. 3 (2019), 74-79. p. https://doi.org/10.14382/epitoanyag-jsbcm.2019.13

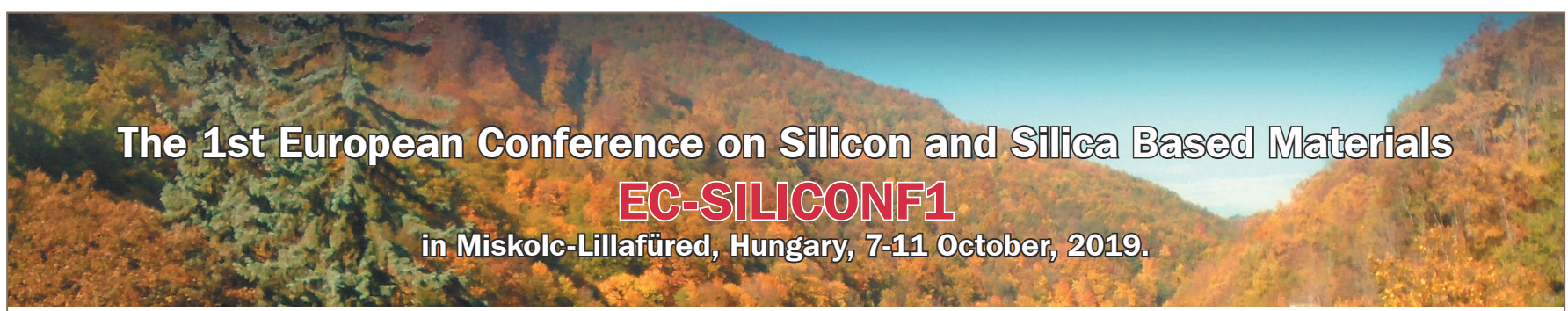

The aims of the ec-siliconf1 are the creation of an interdisciplinary European and worldwide forum on the silicon and silica content materials and fostering of collaboration among scientists, researchers, PhD students, engineers as well as universities, research institutions and industry.

We hope to see and welcome you in Hungary in the Beech Mountains at Miskolc-Lillafüred in October 7-11 $1^{\text {th }}, 2019$. www.ec-siliconf.eu

Further information can be obtained from conference secretariat by email: euro.siliconf@gmail.com 